\title{
EVALUATION OF SPATIO-TEMPORAL ASPECTS OF LAND USE AND LAND COVER CHANGES IN NAGALAND, NORTH-EAST, INDIA
}

\author{
Nesatalu Hiese*, Zavei Hiese, Ditho Katiry, Thsope Medo, Melevolu Hiese \\ Nagaland Science \& Technology Council (NASTEC) \\ Department of Science \& Technology \\ Below Civil Secretariat \\ Kohima - 707004, Nagaland \\ Ph: +91 9856072064, +918132059332 \\ Email: nhiese@rediffmail.com \\ www.dst.nagaland.gov.in
}

KEYWORDS: Land use/ land cover, changes analysis, deforestation, shifting cultivation

\begin{abstract}
:
Land use is a dynamic phenomenon, changing with time and space. Land use/land cover (LULC) information and its periodic changes has become crucial to carry out the prediction to the dynamical change of land use. This study analyzed the spatial and temporal changes in land use that has taken place in Nagaland over the last 10 years (2005-2016). It has been observed that the dynamic change in land use and land cover has been mainly caused by the traditional practice of jhum cultivation, also known as shifting cultivation in Nagaland, which constitute about $81 \%$ of the total agricultural land. As a result, there is a decline in forest area by $593.87 \mathrm{~km}^{2}(5.66 \%)$ from 2005-2006 to 2015-2016. Concurrently, abandoned jhum land and scrubland has increased by $11.72 \%$ and $24.89 \%$, demonstrating the decreased in jhum/ shifting cultivation cycle. The loss of forest in the last decade was attributed to ever increasing population, putting pressure on demand of jhum/ shifting cultivation and other anthropogenic activities. The degradation of forest is ever increasing, which calls for intervention of appropriate technology and holistic approach to address this issue.
\end{abstract}

\section{INTRODUCTION}

Land use/ land cover change is a key driver of global environmental change since it occurs at spatial and temporal scales. Remote sensing and GIS techniques are important tools for measuring land use/land cover change (Sharma, P.K. et al. 2008). Information on existing LULC, its spatial distribution and change are necessary requirement for any planning (Jaiswal et al, 1999). Over a period of time, LULC change is becoming more rapid due to anthropogenic activities and population pressure. The unsustainable and unplanned exploitation of land resources is of grave concern today.

Land use and land cover (LULC) change has become a central component in current strategies for managing natural resources and monitoring changes. There is a need for spatial and temporal characterization of land cover. Remote Sensing and GIS technologies now provided the potential for mapping and monitoring the spatial extent land use changes. It acts as an effective approach for analyzing the direction, rate and spatial pattern of land use dynamics change. As reliable and timely information is the key to effective planning, it calls for up-todate information on the status of natural resources for developing appropriate strategies for their management, taking into consideration, their limitations and potentials. Land utilization pattern is one of the important elements in the assessment of our natural resources. Information on land cover is fundamental to planning state programmes addressing watershed management, agricultural productivity improvement and scientific research etc.

Nagaland is a mountainous state with a total population is about two million (Census of India, 2011). About $70 \%$ of the total population is dependent on agriculture activities. Terrace and jhum cultivation are the most predominant farming practices in the state. Jhum cultivation, an ancient farming system is thought to have originated in the Neolithic period around $7000 \mathrm{BC}$ (Borthakur, 1982). It is viewed the jhum cultivation as an exploitative system, where the land and its resources are not managed optimally and is taken to be a major cause of deforestation. The aim of the present study is therefore to evaluate the magnitude of landuse change and recognize factors and processes that determine land use change in Nagaland and also attempt to provide baseline information required for planning and evaluation.

\section{STUDY AREA}

Nagaland is a mountainous State, located in the North-eastern part of India sharing its boundary with three states i.e. Arunachal Pradesh on north, Assam on west, Manipur on south and shares an international boundary with Myanmar in the east. It lies between the geographical coordinates of $25^{\circ} 6^{\prime} \mathrm{N}$ and $27^{\circ} 4^{\prime} \mathrm{N}$ latitude and $93^{\circ} 20^{\prime} \mathrm{E}$ and $95^{\circ} 15^{\prime} \mathrm{E}$ longitude covering a total geographical area of $16,579 \mathrm{~km}^{2}$ and a total population of 1,980,602.(Statistical handbook of Nagaland, 2011).

Agriculture is the most important economic activity, covering over $70 \%$ of the state's economy. Other significant economic activity includes forestry and other cottage industries.

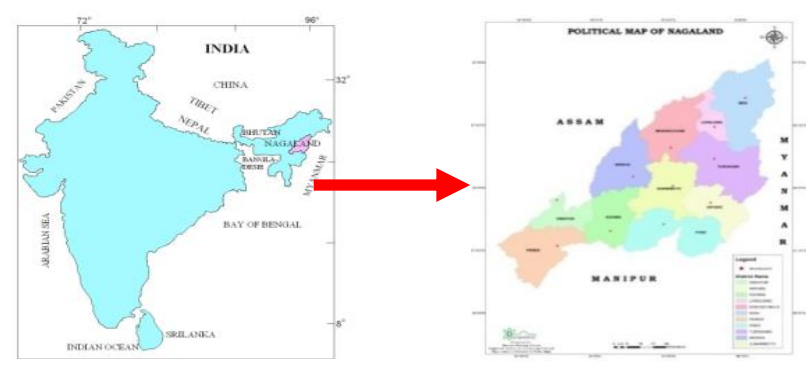

Figure 1. Study area

* Corresponding Author 
Among the various types of agricultural practices, shifting cultivation is the most common practices. It is an integral part of the Nagas as their socio-culture is closely associated with this agricultural practice.

\section{METHODOLOGY}

The methodology used for study of LULC classification and change analysis is based on the interpretation of the satellite imageries of different years and different data sets. Satellite imageries of Landsat MSS and AWiFs of year 2002 were used as a reference. Resourcesat data of IRS P6 of LISS-III for the year 2005-06, 2011-12 and 2015-16 are used for assessing the LULC change in the study area.

Landsat MSS/AWiFs Data were carried out for digital classification using supervised maximum likelihood techniques, which are validated through field work and normalized difference vegetation index (NDVI) to identify and to improve the discrimination between LULC categories. This classification served as a base layer for land use classification. The Landsat data is also used as a reference whenever there is cloud cover in IRS data.

In this study, the Indigenous Indian Remote Sensing (IRS) data of Resourcesat P6 LISS-III image has been used, as this is the dedicated satellite for resource mapping in the country and is best suited for LULC study. The band combination of 4,3,2 of LISS-III provides overall accuracy in classification because of higher spatial resolution of $23.5 \mathrm{~m}$. The corresponding years of 2005-06, 2011-12 and 2015-16 were used for detecting the change. To identify the type of vegetation and crops, three season data of kharif, rabi and zaid is used. These thematic layers of three season data are integrated in GIS platform to form a single LULC layer. These layers are then superimposed on the corresponding different years to detect the changes. This evaluation of the temporal changes of LULC is carried out for every five years to detect the pattern of change.

The pre and post field surveys have been done with GPS and using a set of questionnaires designed for the purpose for ground truth validation and verification of location (latitude and longitude). The Final output map of different years mentioned above were superimposed to identify the changes in land use over a period of ten years.

The procedure adopted in this research work forms the basis for deriving statistics of land use dynamics and subsequently in the overall findings as can be seen in the workflow methodology below in figure 2 .

\subsection{Data Sets used}

Landsat-MSS, AWiFS data, Resourcesat IRS P6 LISS-III of three season data i.e. kharif, rabi and zaid season of 2005-06, 2011-2012, 2015-16, Field work, GPS. The Satellite data obtained are mostly of pre-monsoon and post monsoon to minimise the area of cloud cover.

Technical manual on Land Use/ Land Cover classification and coding system given by National Remote Sensing Centre (NRSC, 2012), was followed.

\subsection{Methods of Change Analysis}

Change detection is the process of identifying differences in the state of an object or phenomenon by observing at different times (Singh, A. 1989). Five main methods of data analysis were adopted in this study.

(i) Change detection on the image of different years.

(ii) Calculation of the area of the resulting land use/land cover classes for each study year and subsequently comparing the results.

(iii) Detailed cross-matrix change analysis.

(iv) Identification of major factors in the landuse change.

(v) Final output layers for decision making.

These methods have been effective in identifying change in the land use types. The comparison of the land use land cover statistics assisted in identifying the percentage change, pattern and rate of change between 2005-06 and 2015-16.

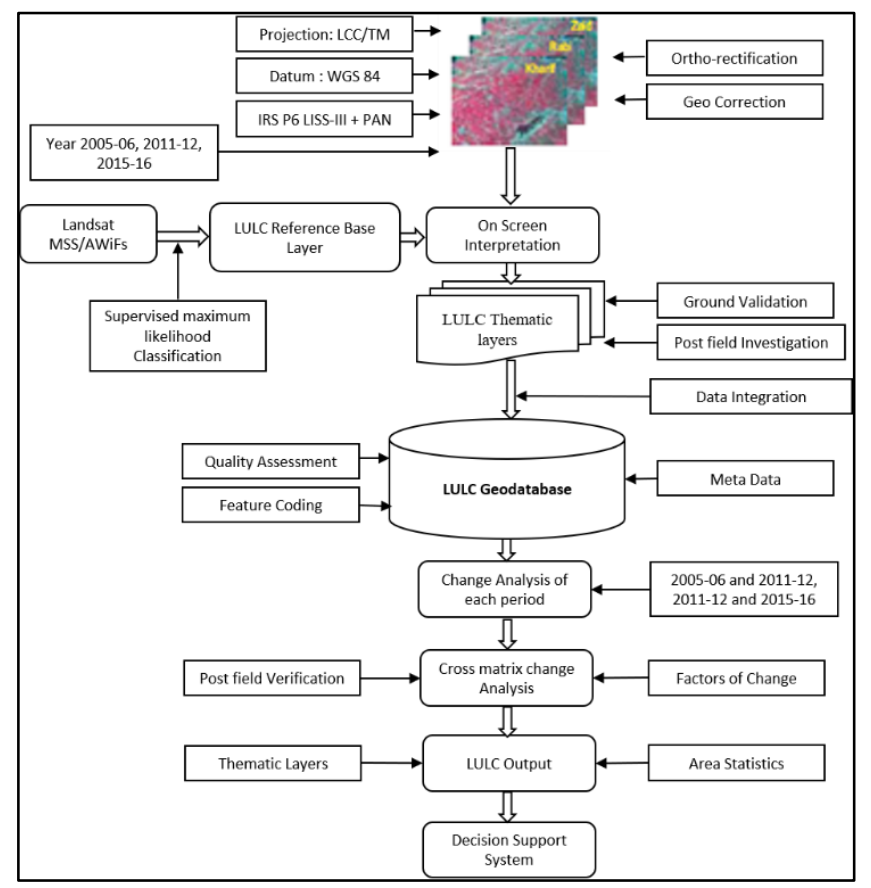

Figure 2: Flow chart showing the methodology

\section{RESULT}

\subsection{Spatial land use pattern and distribution of 2005-06, 2011-12 and 2015-16}

In the study, it has been found that mainly built up, terrace agriculture, shifting cultivation and fallow, scrubland and forest forms the major type of landuse. The different types of cultivation associated with agriculture are found mainly from $300 \mathrm{~m}$ to $2000 \mathrm{~m}$. The Dense forests are mostly found from 1700 $\mathrm{m}$ to $3850 \mathrm{~m}$ and sparse/ scrub forest from $500 \mathrm{~m}$ to $1700 \mathrm{~m}$.

From of the total area of $16579 \mathrm{~km}^{2}$, the built-up or settlement area was $344.22 \mathrm{~km}^{2}$ in 2005 , which was increased to 370.41 $\mathrm{km}^{2}$ in 2016, Forests area has been decreased from 10484.80 $\mathrm{km}^{2}$ to $9890.94 \mathrm{~km}^{2}$ in 2016 . Scrubland has been increasing from $2116.31 \mathrm{~km}^{2}$ to $2643.14 \mathrm{~km}^{2}$. Current shifting cultivation has increase from $1098 \mathrm{~km}^{2}$ to $1150.07 \mathrm{~km}^{2}$ in 2005 which has again decrease to $953.71 \mathrm{~km}^{2}$ in 2016 . 


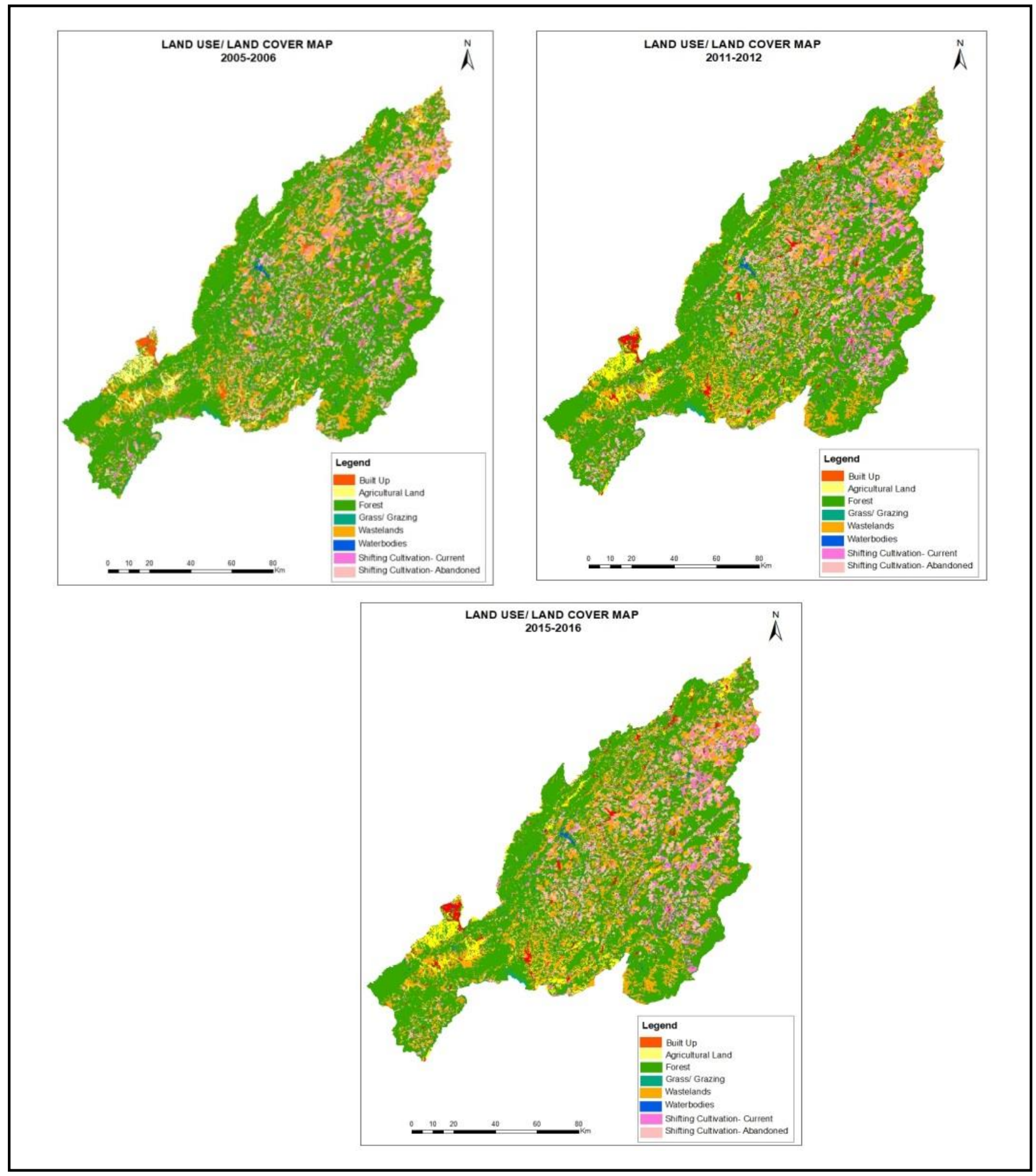

Figure 3: Land use map of 2005-06, 2011-12, 2015-16 


\begin{tabular}{|c|c|c|c|c|}
\hline \multirow[b]{2}{*}{ SI.No } & \multirow[b]{2}{*}{ Level-1 } & \multirow[b]{2}{*}{ 2005-06 } & \multicolumn{2}{|c|}{ Area in $\mathrm{km}^{2}$} \\
\hline & & & 2011-12 & 2015-16 \\
\hline 1 & Built-up & 344.22 & 364.43 & 370.41 \\
\hline 2 & Agricultural Land & 597.76 & 575.25 & 646.06 \\
\hline 3 & Forest & 10484.80 & 10322.49 & 9890.94 \\
\hline 4 & Grass/Grazing Land & 24.55 & 18.60 & 18.92 \\
\hline 5 & Wastelands- Scrubland & 2116.31 & 2258.82 & 2643.14 \\
\hline 6 & Waterbodies & 201.02 & 201.02 & 201.02 \\
\hline 7 & Shifting Cultivation -Current & 1150.07 & 1111.33 & 953.71 \\
\hline 8 & Shifting Cultivation -Abandoned & 1660.27 & 1866.35 & 1854.81 \\
\hline & Total & 16579 & 16579 & 16579 \\
\hline
\end{tabular}

Table 1: Overview of land use pattern for the past 10 Years

\subsection{Land Use Change Analysis}

Landuse change analysis was carried out to study the pattern of change and rate of change between 2005-06 and 2015-16. Cross matrix change analysis was performed to see the overall changes between classes across the landscape.

The period between 2005-2006 to 2015-2016, there is an increase in built up area by $26.19 \mathrm{~km}^{2}$ which is $7.61 \%$, agricultural land (permanent) is increased by $48.85 \mathrm{~km}^{2}$. i.e. $8 \%$, scrubland also increased by $526.83 \mathrm{~km}^{2}$ which is $24.89 \%$ and shifting cultivation-abandoned (fallow) by $194.53 \mathrm{~km}^{2}$, which is increase by $11.72 \%$, whereas forest area has decreased by an area of $593.87 \mathrm{~km}^{2}$ i.e. by $5.63 \%$, grass land by $5.63 \mathrm{~km}^{2}$, and shifting cultivation-current by $196.36 \mathrm{~km}^{2}$ which is reduced by $17.07 \%$.

\begin{tabular}{|c|c|c|c|c|c|}
\hline $\begin{array}{l}\text { Sl. } \\
\text { No }\end{array}$ & Level-1 & $\begin{array}{l}\text { Year 05- } \\
06\end{array}$ & $\begin{array}{c}\text { Year 15- } \\
16\end{array}$ & $\begin{array}{l}\text { Change } \\
\text { in } \mathbf{K} \mathbf{m}^{2}\end{array}$ & $\begin{array}{c}\text { Change } \\
\text { in \% }\end{array}$ \\
\hline 1 & Built-up & 344.22 & 370.41 & 26.19 & 7.61 \\
\hline 2 & $\begin{array}{l}\text { Agricultural } \\
\text { Land }\end{array}$ & 597.76 & 646.06 & 48.30 & 8.08 \\
\hline 3 & Forest & 10484.80 & 9890.94 & -593.87 & -5.66 \\
\hline 4 & Grazing Land & 24.55 & 18.92 & -5.63 & -22.93 \\
\hline 5 & $\begin{array}{l}\text { Wasteland- } \\
\text { Scrubland }\end{array}$ & 2116.31 & 2643.14 & 526.83 & 24.89 \\
\hline 6 & Water bodies & 201.02 & 201.02 & 0.00 & \\
\hline 7 & $\begin{array}{l}\text { Shifting } \\
\text { Cultivation - } \\
\text { Current }\end{array}$ & 1150.07 & 953.71 & -196.36 & -17.07 \\
\hline \multirow[t]{2}{*}{8} & $\begin{array}{l}\text { Shifting } \\
\text { Cultivation - } \\
\text { Abandoned }\end{array}$ & 1660.27 & 1854.81 & 194.53 & 11.72 \\
\hline & Total & 16579.00 & 16579.00 & & \\
\hline
\end{tabular}

\subsection{Land Use Change Processes}

The processes of land use change are shown in Table 3 . Deforestation during the period of 2005-2012, was $162.31 \mathrm{~km}^{2}$, which was mainly caused by shifting cultivation (both current \& abandoned). At the same time, shifting cultivation (both) area was replaced by scrubland by $298.33 \mathrm{~km}^{2}$. Some forest recovery is shown through nature recovery (scrubland to forest) by $517.12 \mathrm{~km}^{2}$. This shows that there is a decrease in shifting cultivation-current in this period.

During the period of 2012-2016, deforestation was more intense than the previous periods by an area of $269.24 \mathrm{~km}^{2}$. Scrubland was more predominant by $911.29 \mathrm{~km}^{2}$, which shows that the shifting/ jhum cultivation cycle has been reduced.

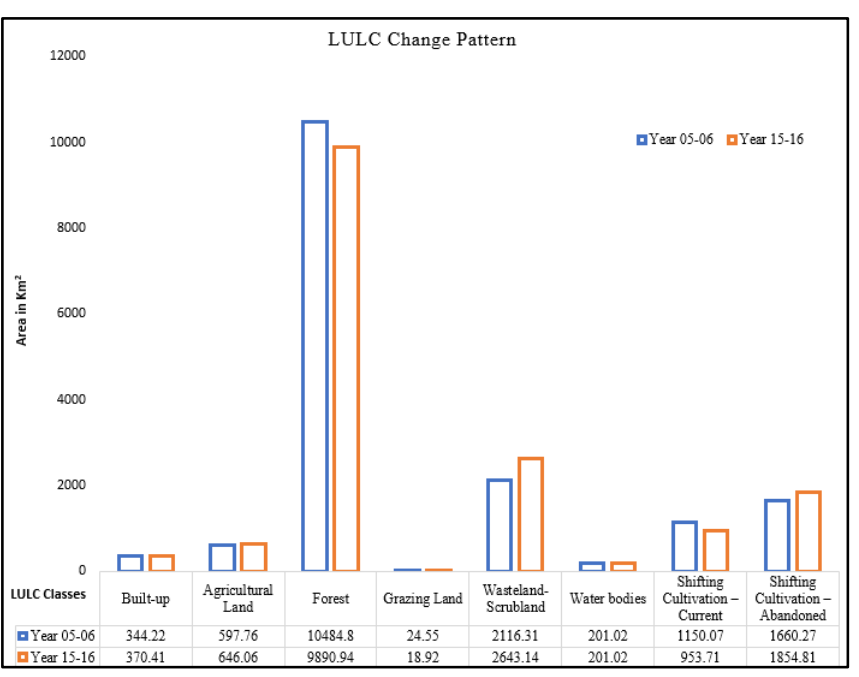

Figure 4: Bar plot showing the land use changing pattern for 10 years. 


\begin{tabular}{|c|c|c|c|c|c|c|c|c|c|c|c|c|c|}
\hline & & \multicolumn{12}{|c|}{ Year 2011-12 } \\
\hline \multirow{13}{*}{ 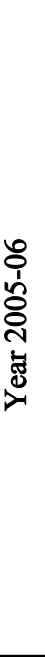 } & Code & 18 & 19 & 20 & 22 & 23 & 26 & 27 & 29 & 34 & 35 & 52 & 53 \\
\hline & 18 & 35.77 & & & & & 0.82 & & & & & 0.25 & 6.60 \\
\hline & 19 & & 5.99 & & & & & & & & & & \\
\hline & 20 & & & 5.27 & & & & & & & & 0.11 & 0.47 \\
\hline & 22 & & & & 96.62 & & & & & & 0.04 & 0.02 & \\
\hline & 23 & & & & & 7.29 & & & & & & & 0.19 \\
\hline & 26 & & & & & & 4099.68 & 94.80 & 0.24 & & 0.12 & 123.95 & 68.14 \\
\hline & 27 & & & & 1.13 & & 394.85 & 4482.18 & 0.34 & 0.86 & & 383.45 & 362.08 \\
\hline & 29 & & & & & & 0.52 & 2.66 & 17.71 & 1.35 & 2.31 & & \\
\hline & 34 & & & & & & 6.41 & 361.79 & & 391.21 & 86.93 & 61.98 & 21.09 \\
\hline & 35 & 0.07 & & & 0.39 & & 17.69 & 130.77 & & 211.40 & 658.21 & 78.54 & 8.52 \\
\hline & 52 & & & & 0.16 & & 6.73 & 143.12 & & 204.24 & 44.36 & 154.14 & 592.33 \\
\hline & 53 & & & & & 0.08 & 0.74 & 123.30 & & 147.30 & 405.38 & 250.20 & 731.70 \\
\hline
\end{tabular}

Table 3: Cross matrix change analysis of major land use classes between 2005-06 and 2011-12

\begin{tabular}{|c|c|c|c|c|c|c|c|c|c|c|c|c|}
\hline & \multirow[b]{2}{*}{ Code } & \multicolumn{11}{|c|}{ Year 2015-2016 } \\
\hline \multirow{12}{*}{ 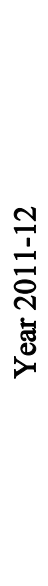 } & & 18 & 19 & 20 & 22 & 23 & 26 & 27 & 34 & 35 & 52 & 53 \\
\hline & 18 & 293.97 & 34.17 & & & 0.03 & & & & & & 1.60 \\
\hline & 19 & 6.41 & 0.01 & & & & & & & & & \\
\hline & 20 & & & 5.56 & & & & & & & & \\
\hline & 22 & & & & 111.09 & & & & & & & 0.50 \\
\hline & 23 & & & & & 8.45 & & 0.27 & & & 0.02 & \\
\hline & 26 & & & & 0.25 & & 4769.66 & 7.54 & & 8.11 & 62.47 & 47.91 \\
\hline & 27 & & & & 4.74 & & 449.86 & 3861.66 & & 1.31 & 210.12 & 120.75 \\
\hline & 34 & & & & 2.03 & & 7.46 & 200.28 & 760.95 & 9.13 & 113.26 & 19.03 \\
\hline & 35 & & & & 2.18 & & 0.02 & 55.35 & 167.60 & 792.97 & 107.48 & 6.36 \\
\hline & 52 & & & & 0.10 & & 0.40 & 1.84 & 47.18 & 103.45 & 164.79 & 848.38 \\
\hline & 53 & & & & 0.58 & & 0.18 & 40.57 & 177.57 & 583.09 & 293.08 & 810.28 \\
\hline
\end{tabular}

Table 4: Cross matrix change analysis of major land use classes between 2011-12 and 2015-16

\begin{tabular}{|c|c|c|}
\hline \multirow{8}{*}{$\begin{array}{l}\text { No Change } \\
\text { Major Changes } \\
\text { Class Interchange }\end{array}$} & Code no & Classes \\
\hline & 18 & Forest - Evergreen / Semi evergreen - Dense / Closed \\
\hline & 19 & Forest - Evergreen / Semi evergreen - Open \\
\hline & 20 & Forest - Deciduous - Dense / Closed \\
\hline & 22 & Forest - Forest Plantation - Forest Plantation \\
\hline & 23 & Forest-Scrub Forest - Scrub Forest \\
\hline & 26 & Forest - Tree Clad Area - Dense / Closed \\
\hline & 27 & Forest - Tree Clad Area - Open \\
\hline \multirow{4}{*}{$\begin{array}{l}\text { Coding from technical manual- National } \\
\text { land use land cover, National Remote } \\
\text { Sensing Centre (NRSC), } 2012 \text {. }\end{array}$} & 34 & Wastelands - Scrub land - Dense / closed \\
\hline & 35 & Wastelands - Scrub land - Open \\
\hline & 52 & Shifting Cultivation - Current \\
\hline & 53 & Shifting Cultivation - Abandoned \\
\hline
\end{tabular}




\section{DISCUSSION AND CONCLUSION}

The study depicts the general type of land use/land cover pattern and its changes of Nagaland State. One significant change observed is the large-scale decrease in forest area as a result of jhum/ shifting cultivation. This is due to $70 \%$ of the State population depends on Agriculture (Economic Survey of Nagaland 2010-2011). This can be attributed due to rapid population growth

As evident from the study, one of the main driving agents of change in land use / land cover in the State is the practice of slash and burn commonly known as jhum / shifting cultivation. Out of the total agriculture area of $3454.58 \mathrm{~km}^{2}$, about 2808.52 $(81 \%)$ are under jhum/ shifting cultivation. This large-scale deforestation due to jhum/ shifting cultivation has contributed to high run-off of surface water thereby affecting the soil fertility too.

Jhum cultivation is the most primitive cultivation practice of the tribes of Nagaland. Jhum cultivation is a land use system described as based on a traditional, community wide, largely self-contained and ritually sanctioned way of life. The sociocultural life of the practicing communities is woven around it and is regulated according to jhum calendar (Katherine, W. 1991). The practices of Jhum are thus not merely another exercise by the tribal's for their sustenance, but a traditional method of earning a livelihood and traditional farming system (Gupta, 2005).

The jhum/ shifting cultivation areas when left abandoned for few years, this automatically changes into scrubland. From the study, it is found that there has been a slight decreased of jhum/ shifting cultivation current. It is also observed that there has been an increase in areas of abandoned jhum land and scrub land by $11.72 \%$ and $24.89 \%$ respectively, which indicated that the jhum cycle has been reduced over the past 10 years.

There has also been an increase in Urban built up area by $7.61 \%$ as large area of scrubland and forest has been converted to settlement area and some of the scrubland has converted into bricks industries especially in the Dimapur District.

The total forest area has been decreased by $593.87 \mathrm{~km}^{2}(5.66 \%)$ over the past 10 years. The reason for this decrease is due to the dominant agricultural practice of shifting cultivation. The forest area is degrading at an alarming rate. Also, inside the reserved forest area, it is noticed that large area of forest is degraded due to timber extraction and other anthropogenic activities. One case study is observed in the northern part of Mokokchung district, where large areas of forest area have converted to coal mining area.

From the study, it is observed that forest cover has been converted to shifting cultivation-current by total area of 779.90 $\mathrm{km}^{2}$, and shifting cultivation-abandon by an area of $598.88 \mathrm{~km}^{2}$. Other observations includes an increase in forest area by 772.47 $\mathrm{km}^{2}$ from scrubland area, shifting cultivation areas both current and abandon has been change to scrubland by an area of 400.21 $\mathrm{km}^{2}$. This indicates the class interchange has taken place from one class to another.

The change in land use and land cover over the last decades has attributed to ever increasing population which puts pressure on land due to increase demand on agricultural land, fuel-wood and timber requirement and diversion of forest lands to nonforest uses and other anthropogenic activities. The rampant destruction of forest at an alarming rate calls for intervention at a policy level as well addressing the factors leading to deforestation through appropriate technology or approaches.

Shifting cultivation is the most complex and multifaceted form of agriculture in the world (Thrupp, L.A., ed. 1997). Scientists today view jhum/ shifting cultivation as a catastrophic degradation of biodiversity and environment and a faulty land use practice having very low output-input ratio (Tripathi and Barik, 2003). Animal husbandry are against jhuming as they need more land for grazing but agriculturist are for jhuming. Forest Department are against jhuming which causes land and soil degradation. On the other hand, from Agriculture and Ethnobotanical point of view, jhuming holds good for production of food and other resources. Likewise, debate can go on, which requires more scientific studies to identified appropriate agro-forest farming system through integrating jhum cultivations with trees plantation or plantation through cultivation. Identification of cash crops such as ginger, cardamon, fruits, etc. and introduction of the same are certain parameters to be taken into consideration for sustainable farming system.

\section{ACKNOWLEDGEMENT}

We want to thank National Remote Sensing Centre (NRSC), Department of Space, Government of India for funding this project and for technical support.

\section{REFERENCES}

Borthakur, D. N. 1982. Agriculture in the 1980's: strategy for development in the potential areas- North Eastern Hill Region, Paper Presented at the Silver Jubilee Conference of Agriculture Society of India, Calcutta.

Census of India 2011. http://www.census2011.co.in/ census/state/nagaland.html.

Economic Survey of Nagaland 2010-2011, Directorate of Economics \& Statistics, Nagaland, 2012, pg. 10

Gupta V 2005. Jhum cultivation practices of the Bangnis (Nishis) of Arunachal Pradesh, Indian Journal of Traditional Knowledge, 4 (1): 47-56.

Jaiswal, Rajeev Kumar, Saxena Rajesh and MukhuerjeeSaumitra., 1999. Application of Remote Sensing technology for land use/land cover change analysis. Journal of the Indian Society of Remote Sensing 272.

Katherine, W. 1991. Shifting cultivators-localtechnical knowledge and natural resource management in the humid tropics, Community Forestry Note 8, FAO UN, Rome.

NRSC, 2012, Technical Manual- National Land Use Land Cover (Mapping using Multi-temporal Satellite Data), National Remote Sensing Centre, Indian Space Research Organization, Department of Space, Govt. of India, Hyderabad.

Sharma, P.K., Lahkar, B.P., Ghosh, S., Rabha, A., Das, J.P., Nath, N.K., Dey, S. and Brahma, N. 2008. Land-use and landcover change and future implication analysis in Manas National 
Park, India using multi-temporal satellite data. Current Science 95. (2):223-227

Singh, A. (1989), Digital change detection techniques using remotely sensed data, International Journal of Remote Sensing, 10(6), 989-1003.

Statistical handbook of Nagaland, 2011, Directorate of Economics \& Statistics, Kohima, Nagaland, India.

Thrupp, L.A., ed. 1997. The Diversity and Dynamics of Shifting Cultivation: Myths, Realities, and Policy Implications, World Resources Institute: (1)

Tripathi R S and Barik S K 2003. Shifting cultivation in North East India, In: Bhatt B P, Bujarbaruah K M, Sharma Y P Edts Approaches for increasing agricultural productivity in hill and mountain ecosystem, Patiram, ICAR Research Complex for NEH, Umiam, Meghalaya. 317-322. 